\title{
Governing parameters on xylanase production using developed bioreactor
}

\author{
Chee Keong Lee*, Darah Ibrahim ${ }^{1}$ and Ibrahim Che Omar ${ }^{2}$ \\ ${ }^{1}$ Industrial Biotechnology Research laboratory, School of Biological Sciences, \\ Universiti Sains Malaysia, 11800 Minden, Pulau Pinang, Malaysia. \\ ${ }^{2}$ Campus Jeli, Universiti Malaysia Kelantan, Beg Berkunci No 100, \\ 17600 Jeli, Kelantan, Malaysia. \\ Email: cklee1311@yahoo.co.uk
}

Received 11 August 2014, Received in revised form 12 December 2015, Accepted 15 December 2014

\begin{abstract}
Aims: Chemicals bleaching are common steps in pulp and paper manufacturing process. The reduction of chemical use would result in lower waste treatment costs while minimizes the impact on the environment. This can be achieved using enzyme (xylanase). Compared to submerged fermentation process, the cost for enzyme production is much cheaper using solid state fermentation process (SSF). The present study aimed to examine factors affect xylanase production using developed SSF bioreactor.

Methodology and results: The performance of developed bioreactor namely FERMSOSTAT had been investigated in xylanase production studies. In this studies, local isolate Aspergillus niger USM AI 1 was used together with sugarcane bagasse and palm kernel cake (ratio 1:1), which serve as substrates for xylanase production. The highest xylanase activity and production of $397 \mathrm{U} / \mathrm{g}$ and $103 \mathrm{U} / \mathrm{mg}_{\mathrm{g}}$ glucosamine were obtained, respectively when the fermentation process was carried out under examined enzyme production conditions of $0.5 \mathrm{~kg}$ substrate; $70 \%(\mathrm{w} / \mathrm{w}$ ) moisture content; $30{ }^{\circ} \mathrm{C}$; aeration at $4 \mathrm{~L} / \mathrm{h} . \mathrm{g}$ fermented substrate for $5 \mathrm{~min}$ and mixing at $0.5 \mathrm{rpm}$ for $5 \mathrm{~min}$. On the other hand, compared to initial SSF conditions for xylanase production, xylanase activity increased $681 \%$ after all factors affect xylanase production have been examined.

Conclusion, significance and impact of study: The performance of the newly developed bioreactor is good since it can be used to produce xylanase with high title when compared with previous researcher findings.
\end{abstract}

Keywords: Solid state fermentation, xylanase, Aspergillus niger, sugarcane baggase, palm kernel cake

\section{INTRODUCTION}

Solid state fermentation (SSF) is an alternative for submerged fermentation in the production of biotechnology products such as enzymes, bioactive secondary metabolites, organic acids and so forth. Many researches have been carried out using SSF, in which this contribute to a wide range of applications not only at laboratory scale (Gupte and Madamwar, 1997; GutierrezCorrea and Tengerdy, 1998; Hang and Woodams, 1998; Kotwal et al., 1998; Sekar and Balaraman, 1998) but also at bigger scale (Durand and Chereau, 1988; Durand et al., 1996; Xue et al., 1992; Fernandez et al., 1996). In addition, comparative studies between SSF and submerged (SmF) have claimed many advantageous for the former (Maldonado et al., 1998), which include superior yields and higher concentration of products, simple fermentation equipment required, less effluent production and so forth (Pandey et al., 2008).

The major factors that affect the SSF process include microorganism and substrate, substrate particle size and pre-treatment, moisture level, temperatures, aeration and agitation as well as metabolic heat removal during the fermentation process. On the other hand, selection of an appropriate type of bioreactor is also crucial since different bioreactors have been classified into different groups based on different classification criteria. FERMSOSTAT is a horizontal stirrer drum fermenter and according to Mitchell et al. $(2000 ; 2006)$ classification criterions, it was classified into group III, in which the bed in this bioreactor group is either intermittently or continuously mixed and the air is circulated around the bed but does not forcefully blown through the bed. The aim of this present work was to investigate the performance of developed bioreactor namely FERMSOSTAT in xylanase production studies using Aspergillus niger USM Al 1 grown on sugarcane bagasse and palm kernel cake as substrates.

\section{MATERIALS AND METHODS}

\section{Microorganism}

In this study, local isolate, Aspergillus niger USM AI 1 was 
used and it was obtained from Industrial Biotechnology Research Laboratory (IBRL) culture collection, USM Penang. It was isolated from decayed wood obtained from the Northern Region of Peninsular Malaysia (Lee et al., 2011).

\section{Production of xylanase enzyme using bioreactor}

\section{Spore production and inoculums preparation}

Fungus cultivation for spore production was carried out according to Lee et al. (2011). In this method, fungus spore was obtained after 4 to 5 days growth on Potato Dextrose Agar under room temperature in medium bottles. The extraction of fungus spore was performed using distilled water containing $0.1 \%(\mathrm{w} / \mathrm{v})$ Tween 80 (Smits et al., 1996). The spore concentration was estimated by direct microscopic counting using hemocytometer (Raimbault and Alazard, 1980). The spore suspension at $1 \times 10^{8}$ spore $/ \mathrm{mL}[20 \%(\mathrm{v} / \mathrm{w})]$ was mixed with the prior autoclaved growth medium. This medium was used as inoculums for SSF process.

\section{Substrates sterilization}

Palm kernel cake $(\leq 0.5 \mathrm{~mm})$ and sugarcane bagasse $(\leq 2$ $\mathrm{mm}$ ) at 1:1 ratio were used as substrates for xylanase production. The substrates were manually mixed before being transferred into the FERMSOSTAT through the substrate port located on the top of the fermenter vessel. The substrate was pre-treated cum sterilized in situ by hot air sterilization at $130{ }^{\circ} \mathrm{C}$ for $3 \mathrm{~h}$ (Lonsane et al., 1992a). After the sterilization process, the fermenter and substrates were allowed to cool down before inoculation of the substrates were carried out (Lee et al., 2011).

\section{Medium composition}

The growth medium used in SSF process consisted of mineral salts and trace elements. The composition of the growth medium used was according to Pang et al. (2006). The $\mathrm{pH}$ of the medium was adjusted to 7.0 prior to autoclave. The $\mathrm{pH}$ of the growth medium was not controlled during the course of fermentation.

\section{Inoculation and sampling process}

The inoculation of growth medium containing spore and sampling process during the fermentation process was performed according to Lee et al. (2011). Air/water pressure type of spraying nozzles was used to inoculate solid substrate with growth medium and spore. Sampling process was carried out throughout the fermentation process. About $10 \mathrm{~g}$ of substrate was sampled out each time from three different sampling ports for every $24 \mathrm{~h}$ interval. The substrate was mixed for $5 \mathrm{~min}$ before the sampling process. The sample was used to determine the xylanase activity and fungus biomass.

\section{Enzymes extraction}

The enzyme extraction process was carried out according to Aikat and Bhattacharyya (2000), in which the fermented substrates was mixed with distilled water containing $0.1 \%$ (w/v) Tween 80 . The mixture was stand still for $2 \mathrm{~h}$ under room temperature. The solid residue was then separated from the enzymic solution by filtration through Whatman 1 filter paper.

\section{Determination of xylanase activity}

Xylanase activity was determined according to the method described by Gessesse and Gashe (1997) using oat spelt xylan (Fluka, USA) dissolved in $50 \mathrm{mM}$ citric$\mathrm{NaOH}$ buffer as substrate. One unit of enzyme activity was defined as the amount of enzymes, which catalyzes the liberation of $1 \mu \mathrm{mol}$ of reducing sugar per minute under above specified assayed condition. Enzyme activity was expressed as unit $(U)$ per $g$ of fermented substrate, while enzyme production was expressed as unit (U) per $\mathrm{mg}$ of glucosamine content of the fungus growth. All assays were carried out in triplicates and the results were presented as the mean of the triplicates experiments.

\section{Determination of fungal growth}

The glucosamine content of fungus was used to determine the biomass of $A$. niger USM Al 1. The method used was as described by Swift (1972). The glucosamine was measured spectrophotometrically at $530 \mathrm{~nm}$ using glucosamine as standard.

\section{Xylanase production}

Factors affecting the growth of $A$. niger USM AI 1 and the production of xylanase were examined throughout this present study. The factors examined included amount of substrates, moisture content, incubation temperature, aeration rate and aeration time, mixing speed and mixing interval. The highest xylanase production condition obtained from each experiment was used in the following experiments unless otherwise stated.

\section{Comparison with Trichoderma reesei}

Trichoderma reseei, which is an established culture for cellulases and xylanases production was used as a benchmark for the production of cellulases and xylanases by $A$. niger USM Al 1 using developed bioreactor.

\section{Statistical method}

The significance of difference between each test variable were determined using one way ANOVA analysis and Least Significance Test, computed using SPSS version 11.5 software. All tests were done with a confidence interval of $95 \%$. 


\section{RESULTS AND DISCUSSION}

\section{Effect of different amount of substrate on xylanase production}

The fermentation profiles for xylanase activity and production using different amount of substrate are shown in Figure 1. The results indicated that, significant difference $(p<0.05)$ in xylanase activity was detected when $0.5 \mathrm{~kg}$ of substrate was used compared with the other amount of substrate used in fermentation process. Xylanase production increased with decreasing the used of different amounts of substrate in the fermentation process. About $61 \%$ drops in xylanase activity was detected when the amount of substrate used in the fermentation process was increased by $100 \%$ from $0.5 \mathrm{~kg}$ to $1.0 \mathrm{~kg}$. The results obtained are in agreement with Muhammad et al. (2014) who obtained maximum xylanase activity of $65 \mathrm{U} / \mathrm{g}$ when $10 \mathrm{~g}$ of substrate was used compared to the lowest activity when $30 \mathrm{~g}$ of substrate was used in the study. The maximum level of xylanase activity was detected after 3 days of fermentation process, when $0.5 \mathrm{~kg}$ and $0.75 \mathrm{~kg}$ of substrate were used compared with 4 days, when $1.0 \mathrm{~kg}$ of substrate was used in the fermentation process. The highest xylanase activity of $130 \mathrm{U} / \mathrm{g}$ and $38.7 \mathrm{U} / \mathrm{mg}_{\mathrm{G}}$ glucosamine of xylanase production were gained after 3 and 4 days of fermentation process using $0.5 \mathrm{~kg}$ of substrate, respectively. Only $6 \mathrm{U} / \mathrm{g}$ higher in xylanase activity was obtained although the amount substrate used in the fermentation process increased about 33\% from $0.75 \mathrm{~kg}$ to $1.0 \mathrm{~kg}$.

Significant reduction in xylanase production with an increasing used of amount of substrate in the fermentation process were probably due to different substrate depth. During sterilization, the chances of each substrate particle from thinner substrate depth expose to heat will be higher compared to thicker substrate depth. Substrate with higher exposure to heat during sterlization will be more amenable to microbial attack (Lonsane et al., 1985) and consequently more easily to be degraded by $A$. Niger USM Al 1 in this study. Thus, more enzyme was produced per gram of substrate used.

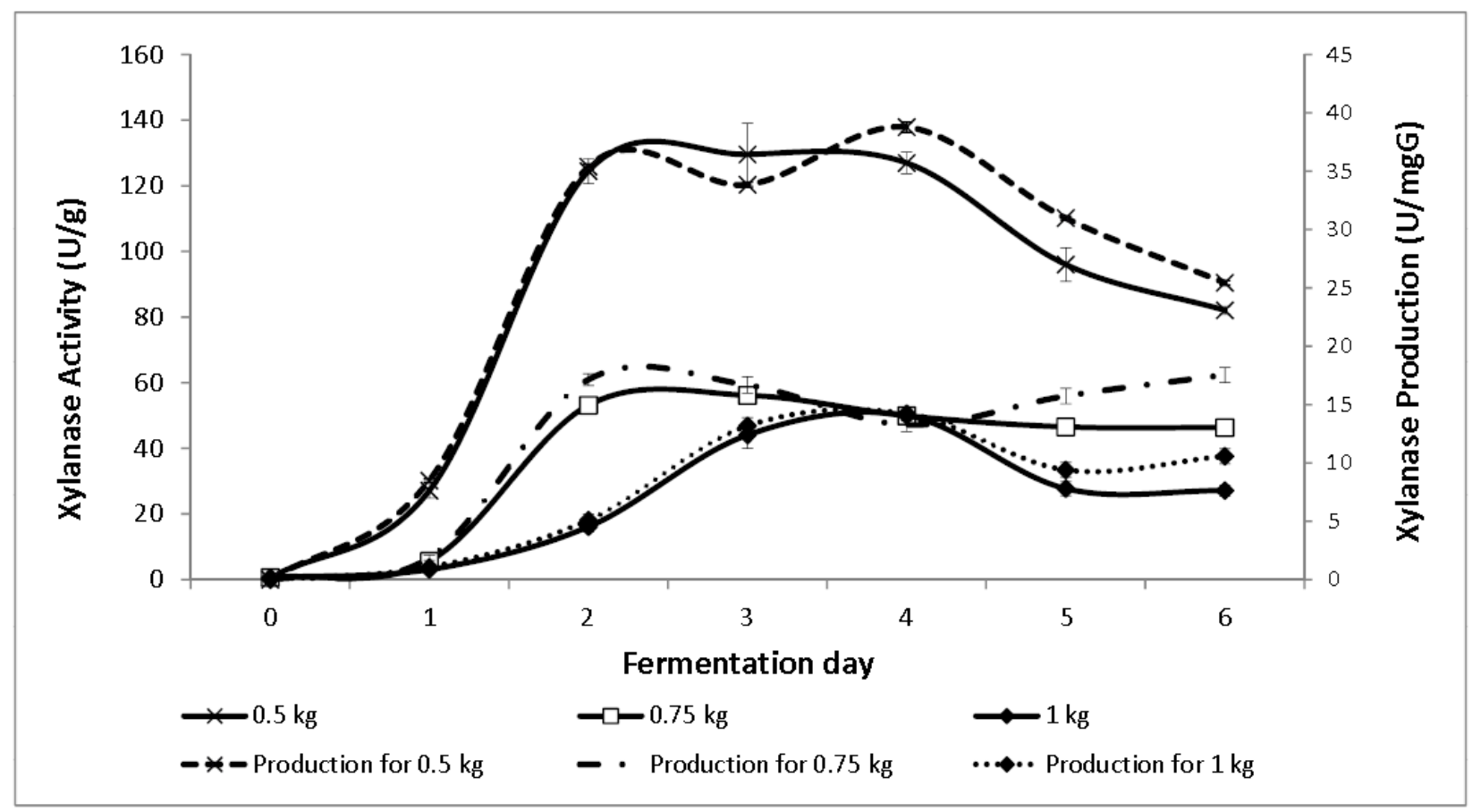

Note: The SSF process was carried out at the indicated amount of substrate; $75 \%(\mathrm{w} / \mathrm{w})$ moisture content; $28{ }^{\circ} \mathrm{C}$; no aeration and mixing for $5 \mathrm{~min}$ at $0.5 \mathrm{rpm}$ for every $24 \mathrm{~h}$ intervals. Arrow bars indicate means with standard error of three replicates.

Figure 1: Effect of different amount substrate on xylanase activity and production. 


\section{Effect of different moisture content on xylanase production}

Figure 2 shows the xylanase activity and production profiles when different moisture contents were used in the fermentation process. The result indicated significant difference $(p<0.05)$ in xylanase activity exhibited at different level of moisture contents used in the fermentation process. Although only $5 \%(\mathrm{w} / \mathrm{w})$ differences in moisture content were used in the fermentation process, it caused about $56 \%$ drop in xylanase activity. This can be seen when $70 \%$ and $75 \%(w / w)$ of moisture content were used in the fermentation process. Highest xylanase activity of $314 \mathrm{U} / \mathrm{g}$ and xylanase production of $91 \mathrm{U} / \mathrm{mg}_{\mathrm{G}}$ glucosamine were obtained after 5 days of fermentation process using selected moisture content of $70 \%(w / w)$. However, these findings were different from Pangiotou et al. (2003) who reported highest xylanase activity at optimum moisture content of $80 \%(\mathrm{w} / \mathrm{w})$ using Fusarium oxysporum grown on corn Stover. In addition, the highest xylanase enzyme production $(64.3 \pm 1.57 \mathrm{U} / \mathrm{g})$ was observed when moisture content of 11:10 (liquid:solid) ratio was but further increased in moisture content resultant decreased in xylanase production (Muhammad et al., 2014). On the other hand, according to Ranganathan and Vasanthy (2011), the highest xylanase (147.3 U/g dry medium) production was obtained when the ratio of paddy husk to liquid fermentation medium of 2:9 was used in SSF process. As reported elsewhere, highest enzymes activities were obtained with initial moisture content of 80\% (w/w) (Abdulah et al., 1985; Dechamps et al., 1985; Roussos et al., 1991; Kalogeris et al., 1998).

On the other hand, xylanase activity reaching maximum level of $207 \mathrm{U} / \mathrm{g}$ and $129 \mathrm{U} / \mathrm{g}$ after 2 days of fermentation process when $65 \%$ and $75 \%(\mathrm{w} / \mathrm{w})$ of moisture content was used, respectively. Figure 2 also revealed that xylanase production dropped drastically after maximum production day when different moisture contents were used except for $65 \%$ moisture content. Xylanase production of $61.8 \mathrm{U} / \mathrm{mg}_{G}$ and $35.7 \mathrm{U} / \mathrm{mg}_{G}$ glucosamine were gained using $65 \%$ and $75 \%(\mathrm{w} / \mathrm{w})$ moisture content, respectively.

The moisture content of the substrate is one of the critical factors influencing the outcome of SSF and is governed by the water-holding-capacity of the substrate, the type of end-product as well as the requirement of the microorganism. The inter particle mass transfer within the solid phase to the growing microorganism depends on the substrate characteristics and the moisture content (Krishna, 1999). In addition, increasing the moisture level above optimum can cause a reduction in enzyme yield due to steric hindrance of the growth of the producer strain by reduction the substrate porosity and alteration of substrate particle structure, thus limiting oxygen transfer (aeration) (Ramesh and Lonsane, 1990).

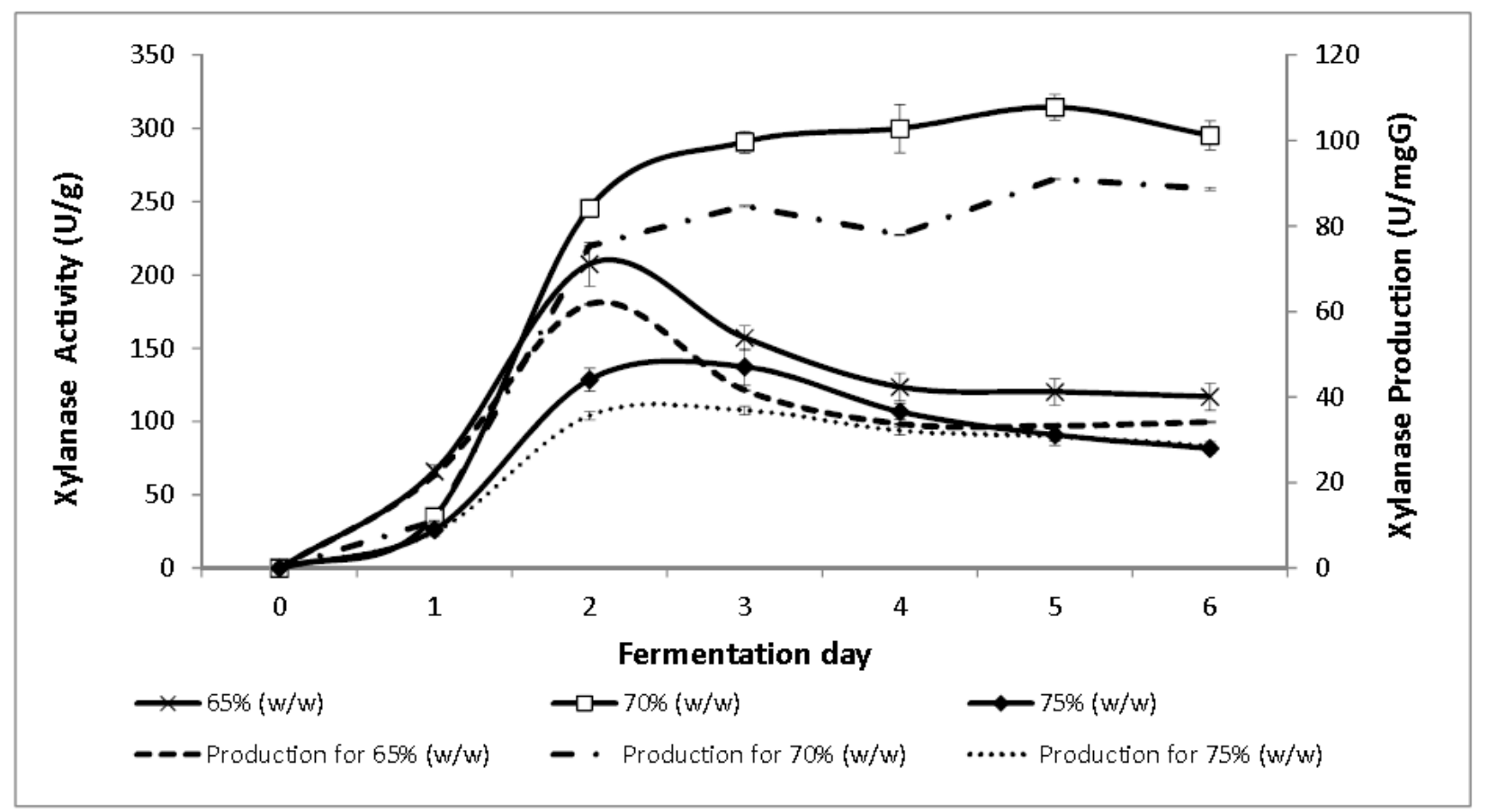

Note: The SSF process was carried out at the indicated moisture content, $0.5 \mathrm{~kg}$ substrate; $28^{\circ} \mathrm{C}$; no aeration and mixing for 5 min at $0.5 \mathrm{rpm}$ for every $24 \mathrm{~h}$ intervals. Arrow bars indicate means with standard error of three replicates.

Figure 2: Effect of different moisture content on xylanase activity and production. 


\section{Effect of different incubation temperature on xylanase production}

The enzyme production increased sharply after day 1 of fermentation and reaching maximum level after 4 to 5 days of fermentation process (Figure 3). Marginal decrease in xylanase activity detected after the optimum fermentation day showed that xylanase are less stable throughout the fermentation process. The highest xylanase activity of $325 \mathrm{U} / \mathrm{g}$ was detected when the fermentation process was carried out for 4 days under selected incubation temperature of $30{ }^{\circ} \mathrm{C}$. However, statistical analysis demonstrated no significant difference $(p>0.05)$ in xylanase activity obtained under selected incubation temperature compared with the other incubation temperature used in the fermentation process. Similar result was reported by Shah and Madamwar (2005), who observed maximum xylanase activity when the SSF process was carried out under the optimum temperature of $30^{\circ} \mathrm{C}$ for 4 days using Aspergillus foetidus MTCC 4898 grown on untreated corncobs moistened with modified Mandels and Strenberg medium. In addition, as reported by Muhammad et al. (2014), the highest xylanase activity $(64.3 \pm 1.3 \mathrm{U} / \mathrm{g})$ was detected when the
SSF process was carried at $30{ }^{\circ} \mathrm{C}$ using Trichoderma viride-IR05. On the other hand, Panagiotou et al. (2003) reported maximum production of xylanase under the optimum temperature of $27{ }^{\circ} \mathrm{C}$ but about $13 \%$ dropped at in production at $30{ }^{\circ} \mathrm{C}$. While, Ncube et al. (2012) obtained optimum xylanase production at when $A$. niger was grown on Jatropha curcas seed cake at $25{ }^{\circ} \mathrm{C}$ in SSF.

As shown in the Figure 3 incubation temperatures showed no significant influence on xylanase production. This is probably because the temperatures used were only differences $2{ }^{\circ} \mathrm{C}$ that not really can shows relatively high differences in the enzyme produced. The incubation temperatures used in this research work were only in between $28^{\circ} \mathrm{C}$ to $32^{\circ} \mathrm{C}$. This was because the fungus $(A$. niger USM Al 1) used in this fermentation process grew well within the temperatures used. Generally the temperature maintained in the SSF system is depends on the growth kinetics of the microorganism employed rather than on the enzyme produced. In addition, similar to this observation is the highest xylanase titers in fungal system have already been reported to happen generally at temperatures, which are optimum for the growth of cultures used in SSF (Biswas et al., 1990).

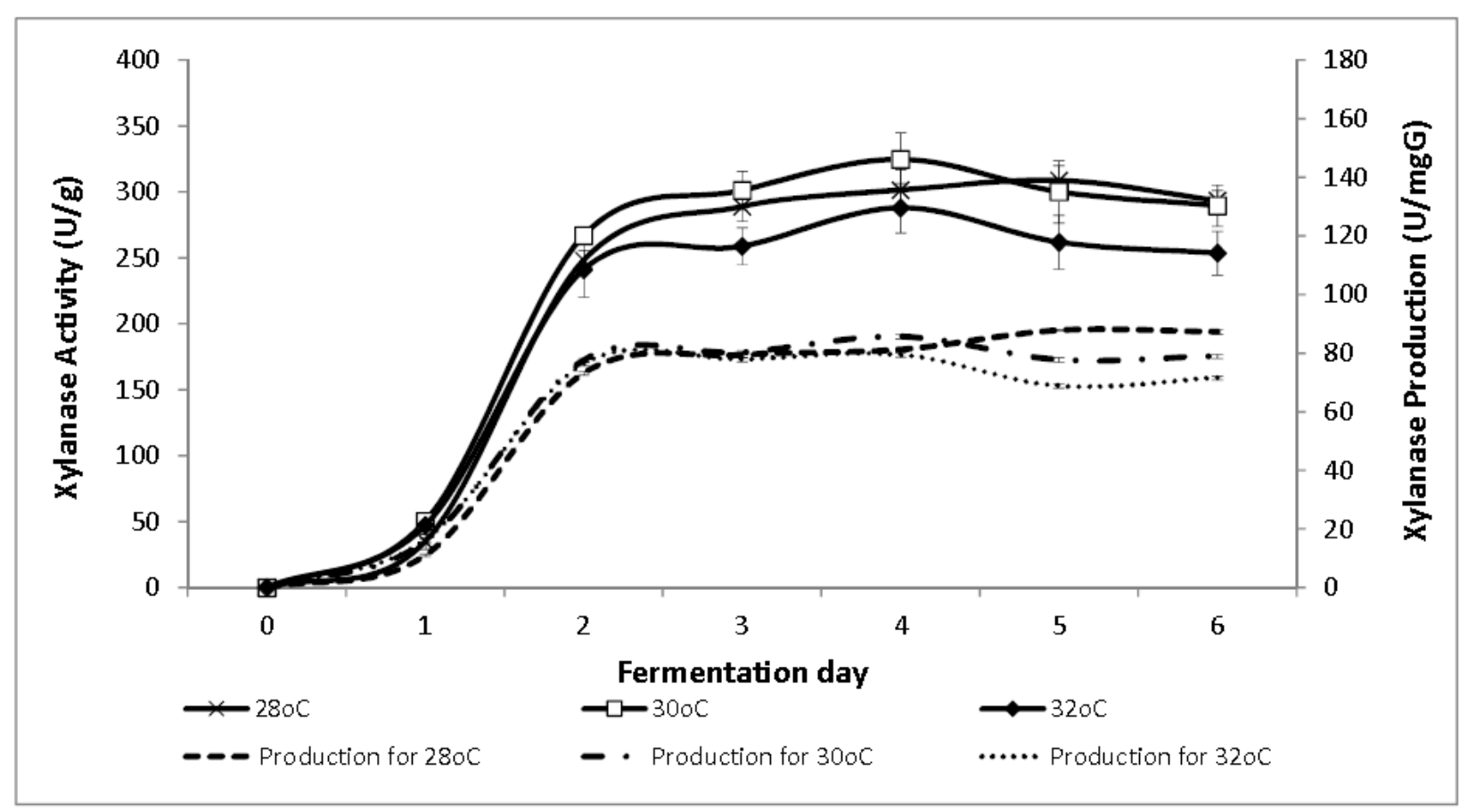

Note: The SSF process was carried out under the indicated incubation temperature, $0.5 \mathrm{~kg}$ substrate; $70 \%$ (w/w) moisture content; no aeration and mixing for $5 \mathrm{~min}$ at $0.5 \mathrm{rpm}$ for every $24 \mathrm{~h}$ intervals. Arrow bars indicate means with standard error of three replicates.

Figure 3: Effect of different incubation temperature on xylanase activity and production. 


\section{Effect of different aeration rate on xylanase production}

The xylanase activity and production profiles under different aeration rates are shown in Figure 4. Significant difference $(p<0.05)$ in xylanase activity was detected at aeration rate of $4 \mathrm{~L} / \mathrm{h} . \mathrm{g}$ fermented substrate compared with other aeration rate used during the fermentation process. For aeration at $4 \mathrm{~L} / \mathrm{h} . \mathrm{g}$ fermented substrate, the xylanase activity reaching maximum level after 5 days of fermentation process compared with 4 days when no aeration and aeration at $2 \mathrm{~L} / \mathrm{h} . \mathrm{g}$ fermented substrate were used. When aeration at 0 L/h.g, 2 L/h.g and 4 L/h.g fermented substrate were used during the fermentation process, their respective maximum xylanase activities detected were $323 \mathrm{U} / \mathrm{g}, 297 \mathrm{U} / \mathrm{g}$ and $403 \mathrm{U} / \mathrm{g}$. On the other hand, as reported by Kalogeris et al. (2003), who found out that xylanase production was increased with increasing airflow rate up to $0.6 \mathrm{~L} / \mathrm{h} . \mathrm{g}$. On the other hand, Rodríguez-Fernández et al. (2011) reported that the highest xylanase activity of $65.38 \mathrm{U} / \mathrm{g}$ was obatined when the SSF process was carried out in a $2 \mathrm{~kg}$ bioreactor using Aspergillus niger F3 grown on citrus peel with airflow rate of $1 \mathrm{Vkg} \mathrm{M}$. About $36 \%$ higher in enzyme activity was detected when the airflow rate used in the fermentation process increased from $2 \mathrm{~L} / \mathrm{h} . \mathrm{g}$ to $4 \mathrm{~L} / \mathrm{h} . \mathrm{g}$ fermented substrate. On the other hand, aeration at 2 L/h.g fermented substrate exhibited xylanase production of $90.7 \mathrm{U} / \mathrm{mg}_{\mathrm{G}}$ glucosamine after 4 days of fermentation process.

Based on the results obatined, it can be concluded that aeration significantly influence the xylanase production. The amount of aeration (air) required in SSF process are depends on many factors such as the product being produced, the substrate depth, metabolic activity of microorganism used and amount of heat to be removed and etc (Lonsane et al., 1985).

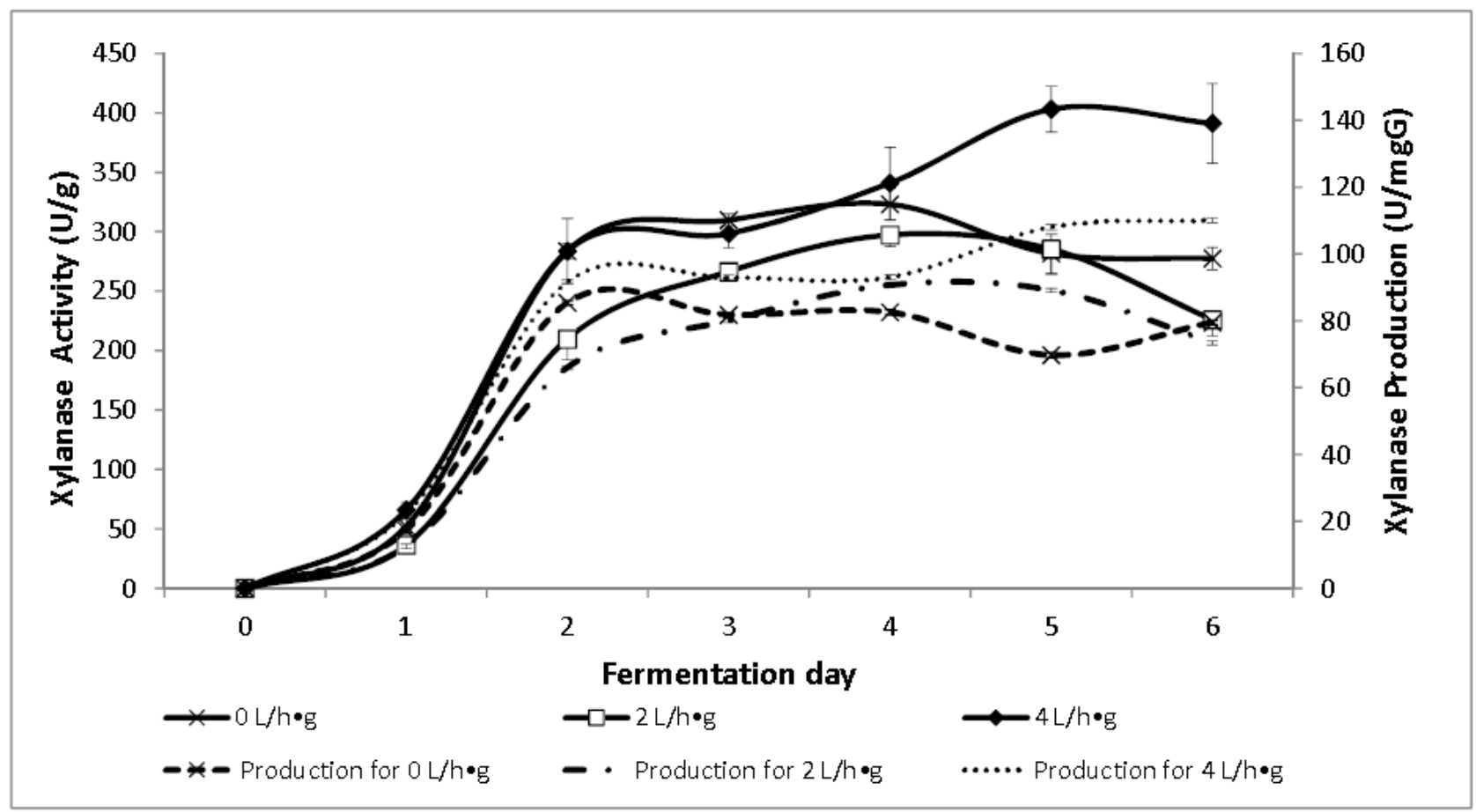

Note: The SSF process was carried out under the indicated aeration rate for $5 \mathrm{~min} ; 0.5 \mathrm{~kg}$ substrate; $70 \%$ (w/w) moisture content; 30 ${ }^{\circ} \mathrm{C}$ and mixing for $5 \mathrm{~min}$ at $0.5 \mathrm{rpm}$ for every $24 \mathrm{~h}$ intervals. Arrow bars indicate means with standard error of three replicates.

Figure 4: Effect of different aeration rate on xylanase activity and production. 


\section{Effect of different aeration time on xylanase production}

As shown in Figure 5 xylanase activity decreased with increasing of aeration time used in the fermentation process. However, the decreased in xylanase activity was not significant $(p>0.05)$. On the other hand, longer aeration time used during the fermentation process resulted in shorter fermentation time required by the enzymes to reach maximum level. These can be seen from 5, 10 and 15 min of aeration times with their respective optimum fermentation days of 5,4 and 3 days. Only 5 min of aeration time was enough for xylanase to achieve optimum activity of $393 \mathrm{U} / \mathrm{g}$ after 5 days of fermentation process. In addition, about $11 \%$ and $13.8 \%$ drop in the enzyme activity were detected when the aeration time used was increased from $5 \mathrm{~min}$ to $10 \mathrm{~min}$ and $15 \mathrm{~min}$, respectively. About $38 \%$ declined in xylanase activity was detected when the aeration time used in the fermentation process was increased from $10 \mathrm{~L} / \mathrm{h} . \mathrm{g}$ to
15 L/h.g bagasse (Milagres et al., 2004). While, according to Rosangela et al. (2013), the highest xylanase activity $(746 \mathrm{U} / \mathrm{g})$ was obatined when the SSF process was carried out in Erlenmeyer flask using Aspergillus oryzae (P6B2) grown on wheat bran with continuous aeration rate of $20 \mathrm{~mL} / \mathrm{min}$. On the other hand, 10 and $15 \mathrm{~min}$ of aeration time shared a similar highest xylanase production of $108 \mathrm{U} / \mathrm{mg}_{\mathrm{G}}$ glucosamine compared with 105 $\mathrm{U} / \mathrm{mg}_{\mathrm{G}}$ glucosamine when $5 \mathrm{~min}$ of aeration time was used. As shown in Figures 4 and 5 higher aeration rate used in the fermentation process resulted in shorter time required for xylanase to achive maximum level. This is mostly due to rapidly decreased moisture level with higher and longer air supply would occur (Milagres et al., 2004).

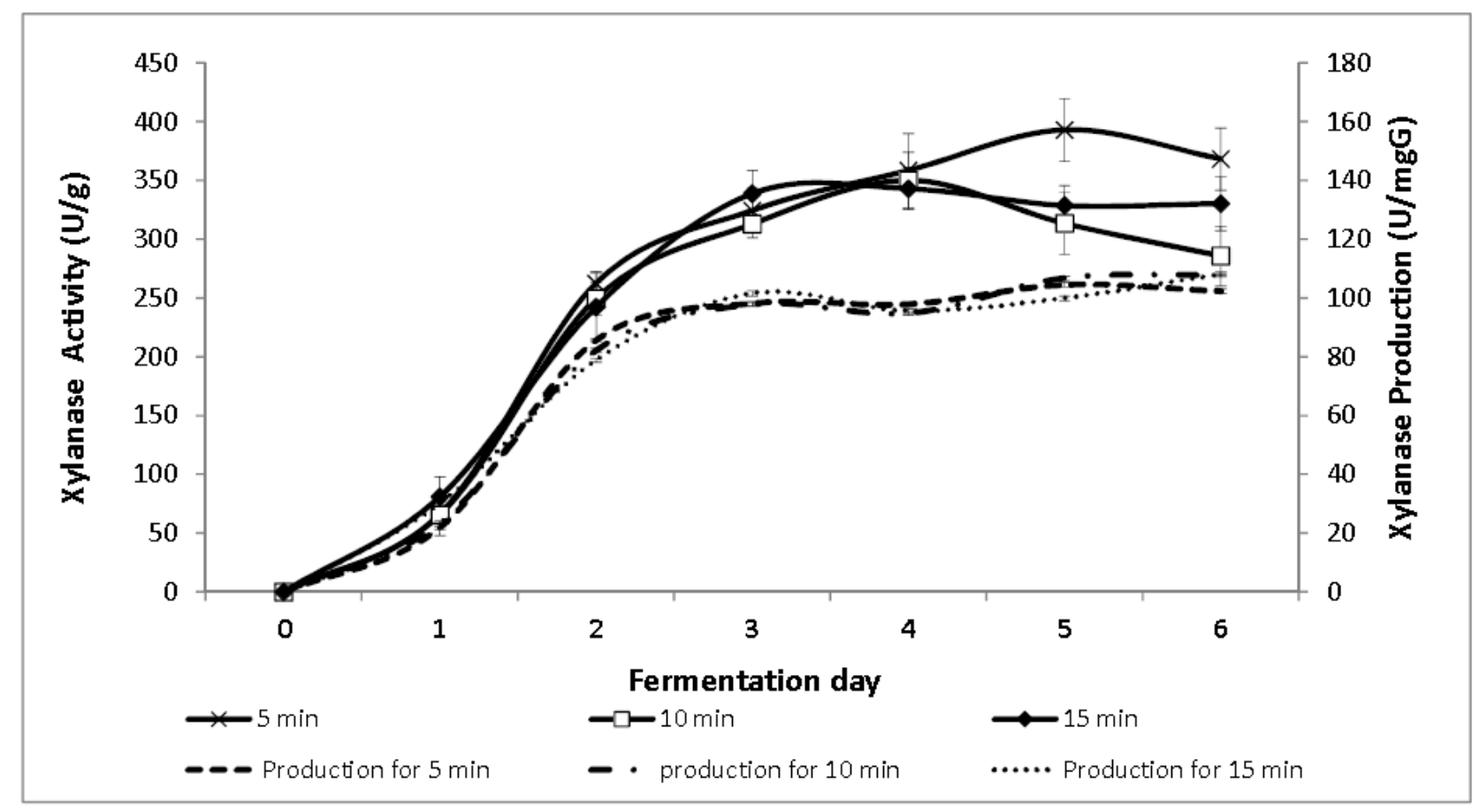

Note: The SSF process was carried out under the indicated aeration time; $0.5 \mathrm{~kg}$ substrate; $70 \%(\mathrm{w} / \mathrm{w})$ moisture content; $30^{\circ} \mathrm{C} ; 4 \mathrm{~L} / \mathrm{h} \cdot \mathrm{g}$ fermented substrate of aeration rate and mixing for $5 \mathrm{~min}$ at $0.5 \mathrm{rpm}$ for every $24 \mathrm{~h}$ intervals. Arrow bars indicate means with standard error of three replicates.

Figure 5: Effect of different aeration time on xylanase activity and production. 


\section{Effect of different mixing speed on xylanase production}

Data presented in Figure 6 shows that xylanase activity required 5 days of fermentation time to reach maximum level regardless the difference in mixing speed used in the fermentation process. In addition, mixing at 1.0 and 1.5 rpm resulted no significant difference $(p>0.05)$ in the enzyme activity. This can be seen when only $3.6 \mathrm{U} / \mathrm{g}$ or $1 \%$ difference in xylanase activity was observed when 1.0 and $1.5 \mathrm{rpm}$ of mixing speed were used during the fermentation process. The highest xylanase activity of 382 $\mathrm{U} / \mathrm{g}$ was obtained when mixing at $0.5 \mathrm{rpm}$ was used in the fermentation process with $103 \mathrm{U} / \mathrm{mg}_{\mathrm{G}}$ glucosamine of enzyme production. However, statistical analysis indicated no significant differences $(p>0.05)$. On the other hand, about $2973 \mathrm{U} / \mathrm{g}$ of xylanase activity was produced by Thermoascus aurantiacus in rotating drum bioreactor mixing at $10 \mathrm{rpm}$ for $1 \mathrm{~min}$ at $3 \mathrm{~h}$ interval using wheat straw as carbon source (Kalogeris et al., 1999). In addition, about $12 \%$ decreased in the enzyme production was detected after the optimum enzyme production days using $1.5 \mathrm{rpm}$ of mixing speed compared to only about $6 \%$ when lower mixing speed was used.

Mixing is important in SSF process as it ensures homogeneity with respect to temperature and gaseous environment (Banks, 1984; Trilli, 1986). In addition, mixing also can promote mass and heat transfers as well as uniform distribution of the nutrients added during the course of fermentation (Lonsane et al., 1992a). The requirement of mixing in SSF system is depend on the type of process, reactor design and the product concerned. Xylanase activity achieved maximum level after 5 days of fermentation process regardless the different mixing rate was used. No great effect of different mixing speed on xylanase production was detected in this study. This probably due to narrow range $(0.5 \mathrm{rpm}$ interval) of mixing speed used.

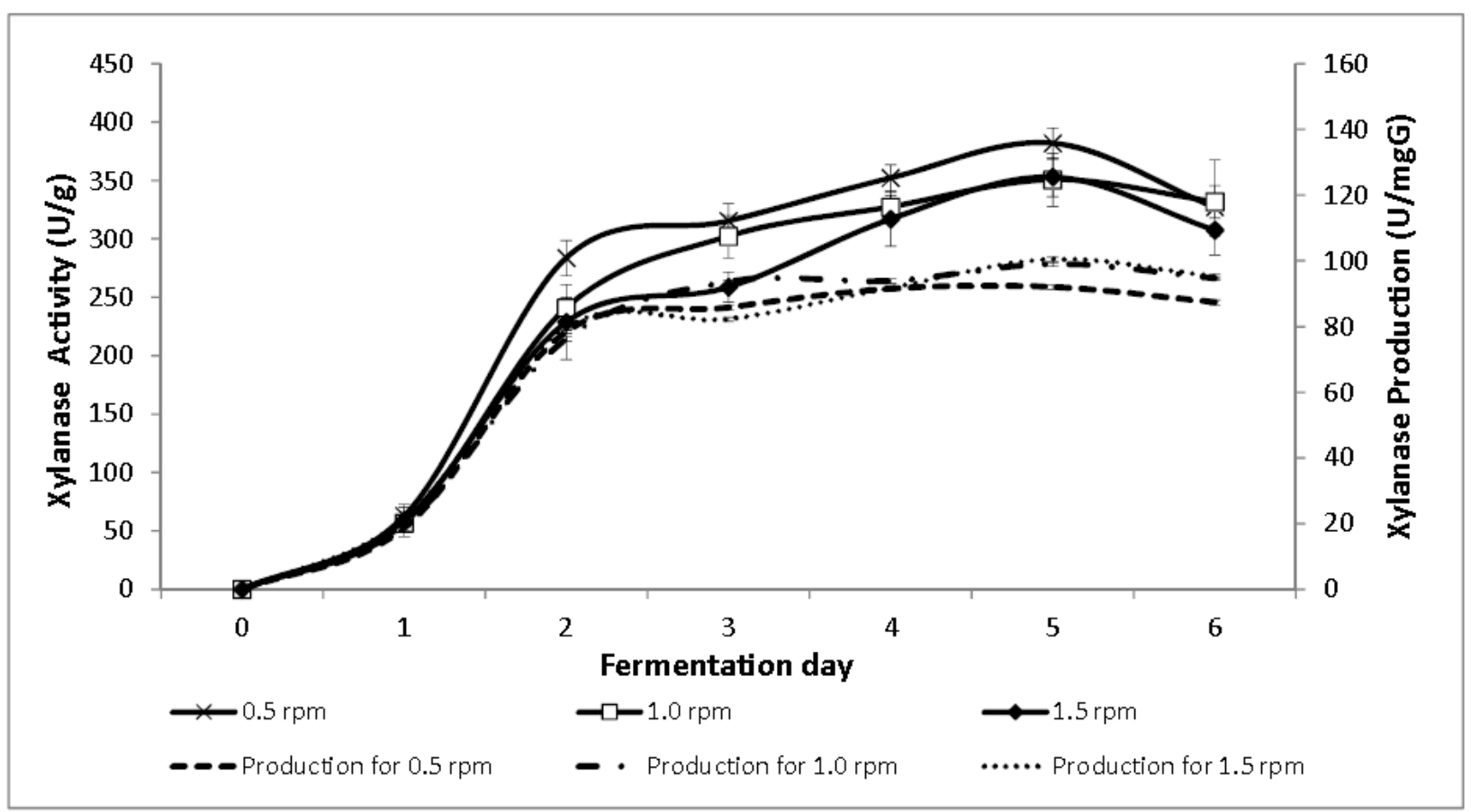

Note: The SSF process was carried out under the indicated mixing speed; $0.5 \mathrm{~kg}$ substrate; $70 \%(\mathrm{w} / \mathrm{w})$ moisture content; $30{ }^{\circ} \mathrm{C}$; aeration at $4 \mathrm{~L} / \mathrm{h} \cdot \mathrm{g}$ fermented substrate for $5 \mathrm{~min}$ and mixing for $5 \mathrm{~min}$ for every $24 \mathrm{~h}$ intervals. Arrow bars indicate means with standard error of three replicates.

Figure 6: Effect of different mixing speed on xylanase activity and production. 


\section{Effect of different mixing interval on xylanase production}

As shown in the Figure 7, xylanase activity increased rapidly from day 1 of fermentation process, reaching the maximum level after 4 days of fermentation process when mixing at every $6 \mathrm{~h}$ and $12 \mathrm{~h}$ interval were used compared with 5 days when mixing at every $24 \mathrm{~h}$ interval was used during the fermentation process. In addition, the enzyme produced decreased with the increased in mixing interval used during the fermentation process. The highest xylanase activity of $397 \mathrm{U} / \mathrm{g}$ obtained under selected mixing interval (24 h interval) was significant difference ( $p$ $<0.05$ ) compared with mixing at every $12 \mathrm{~h}$ and $6 \mathrm{~h}$ interval. At the same time, about $20 \%$ dropped in enzyme activity was detected when the mixing interval used during the fermentation process was increased from $24 \mathrm{~h}$ to $6 \mathrm{~h}$ interval. On the other hand, xylanase production studies indicated that highest xylanase production of $103 \mathrm{U} / \mathrm{mg}_{\mathrm{G}}$ glucosamine was observed when mixing interval of every $24 \mathrm{~h}$ interval was used during the fermentation process compared with about $97.8 \mathrm{U} / \mathrm{mg}_{\mathrm{G}}$ glucosamine when mixing interval of every $12 \mathrm{~h}$ was used.

There has not been any clear principle behind the extent of mixing of the substrate. While most of the researchers have used a low mixing speed (1-15 rpm), some have used high rates of rotation. Different results have been reported by different authors (Silman, 1980; Kargi and Curme, 1985; Kumar and Lonsane, 1987, 1988; Mitchell et al., 1988; Lonsane et al., 1992b). Therefore, it is necessary to study agitation and analyze its effects particularly for a determinate process. The result obtained in this study indicated that higher mixing interval resulted in a declined in enzymes activity. This probably due to problems related to disruption of fungal attachment to the solids substrates and damage to fungal mycelial due to shear forces (Lonsane et al., 1992a).

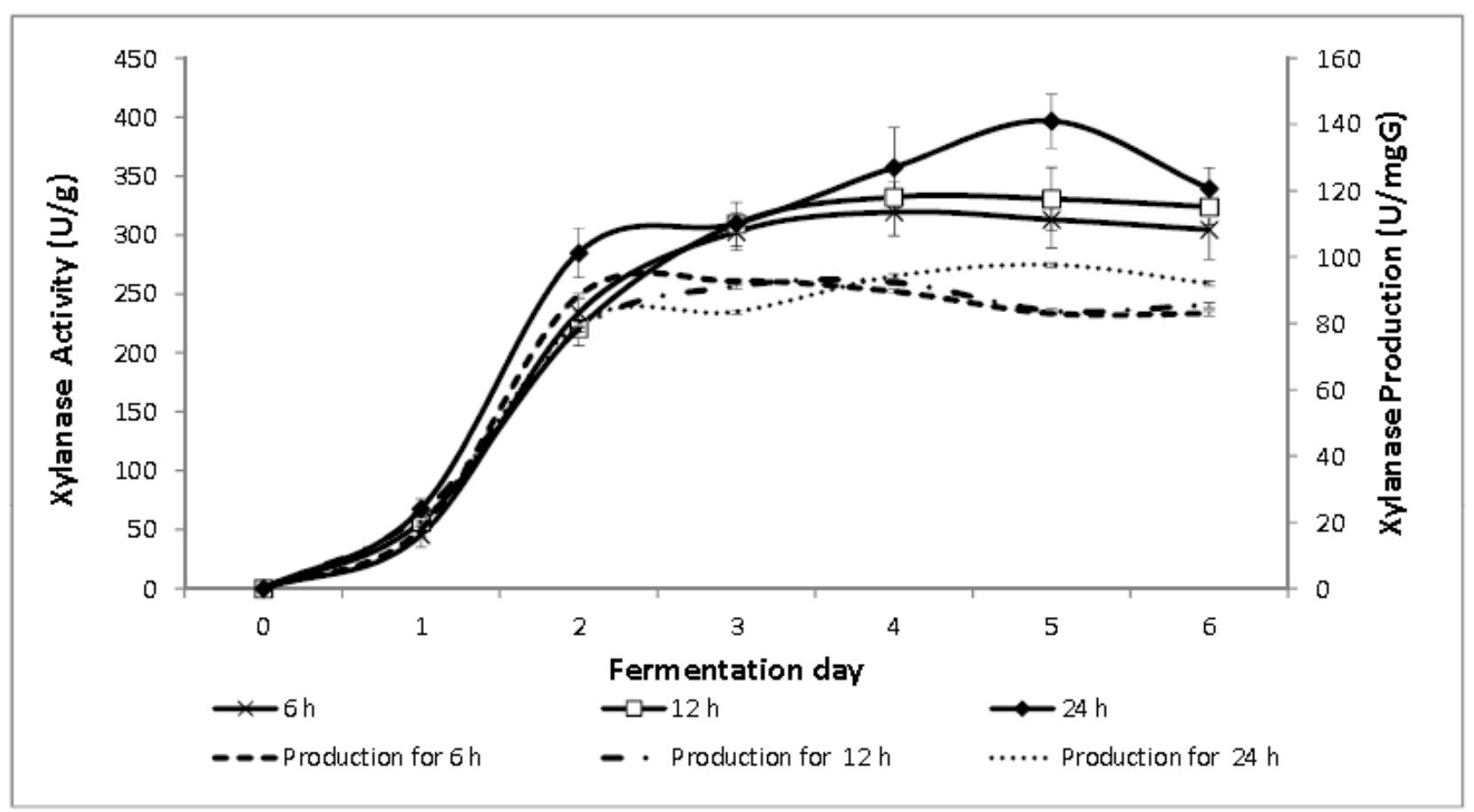

Note: The SSF process was carried out under the indicated mixing interval; $0.5 \mathrm{~kg}$ substrate; $70 \%(\mathrm{w} / \mathrm{w}) \mathrm{moisture}$ content; $30{ }^{\circ} \mathrm{C}$; aeration at $4 \mathrm{~L} / \mathrm{h} \cdot \mathrm{g}$ fermented substrate for $5 \mathrm{~min}$ and mixing at $0.5 \mathrm{rpm}$ for $5 \mathrm{~min}$. Arrow bars indicate means with standard error of three replicates.

Figure 7: Effect of different mixing interval on xylanase activity and production. 


\section{Comparison of xylanase production with T. reesei}

The result indicated that xylanase produced by $T$. reese increased rapidly after 2 days of fermentation process and reaching maximum level after 6 days of fermentation process (Figure 8 ). While, xylanase produced by $A$. niger USM Al 1 increased marginally after 1 day of fermentation process and achieved maximum level after 5 days of fermentation process. However, the result obtained was in disagreement to Shah and Madamwar (2005), who reported maximum xylanase production after 4 days of fermentation process under optimized conditions. In addition, significant differences $(p<0.05)$ in xylanase activity produced by both fungi were observed. This can be seen that highest xylanase activity of $563 \mathrm{U} / \mathrm{g}$ was produced by $T$. reesei, which was about $44 \%$ higher compared with xylanase produced by $A$. niger USM AI $1(391 \mathrm{U} / \mathrm{g})$. On the other hand, the enzyme production of about $204 \mathrm{U} / \mathrm{mg}_{\mathrm{G}}$ glucosamine was obtained by $T$. reesei, which was about 2 fold higher compared with xylanase production (102 U/mg glucosamine) obtained by $A$. niger USM Al 1.

In can be concluded that, enzyme produced by $A$. niger USM Al 1 required shorter fermentation days to achieve maximum level compared to enzymes produced by $T$. reesei. These can be seen when enzymes produced by $T$. reesei reaching maximum level after 6 days of fermentation process compared to 4-5 days when the same enzymes were produced by $A$. niger USM Al 1 . This may probably due to slow growth of $T$. reesei compared to A. niger USM AI 1.

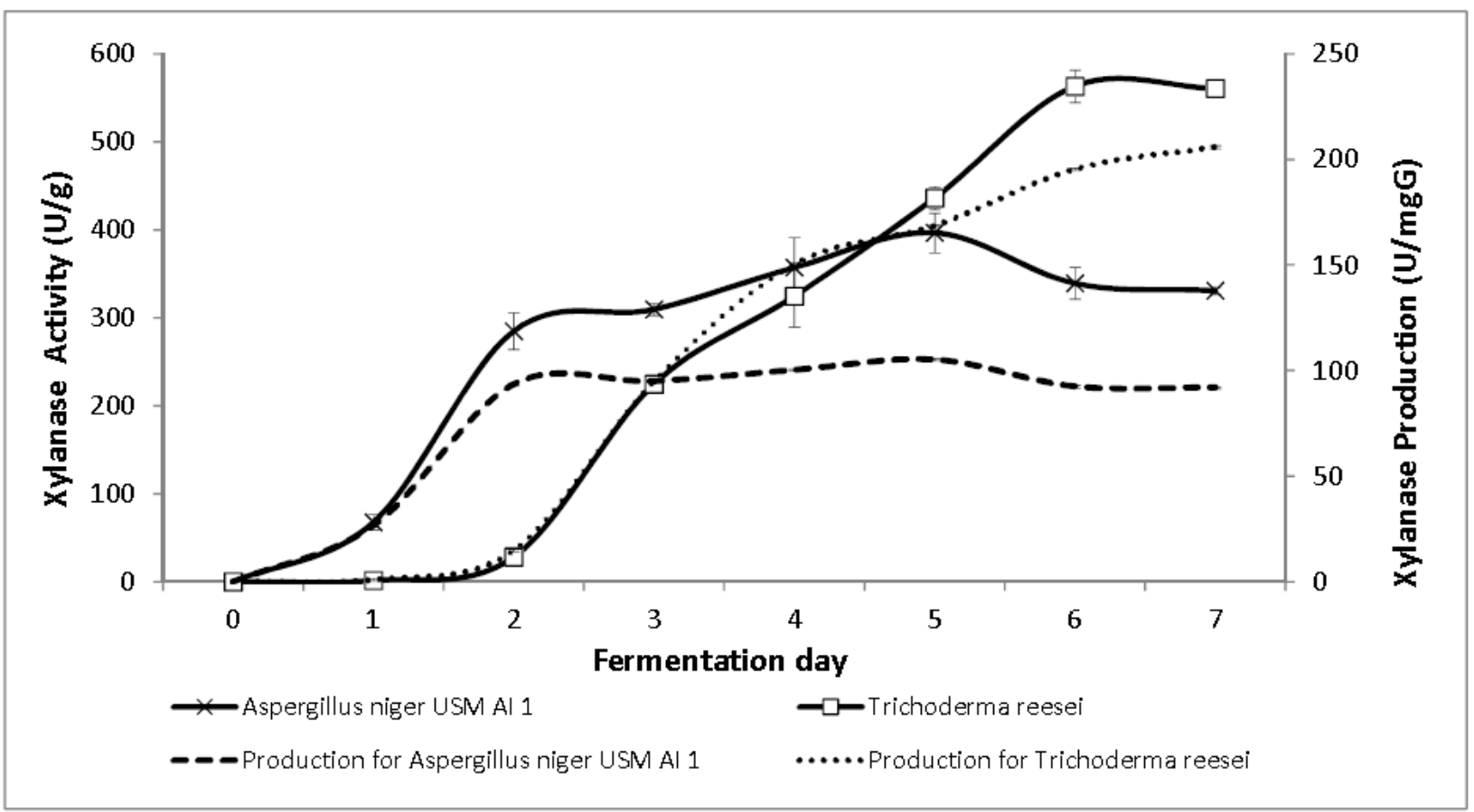

Note: The SSF process was carried out under the indicated fungus; $0.5 \mathrm{~kg}$ substrate; $70 \%(\mathrm{w} / \mathrm{w})$ moisture content; $30{ }^{\circ} \mathrm{C}$; aeration at 4 $\mathrm{L} / \mathrm{h} \cdot \mathrm{g}$ fermented substrate for $5 \mathrm{~min}$ and mixing at $0.5 \mathrm{rpm}$ for $5 \mathrm{~min}$. Arrow bars indicate means with standard error of three replicates.

Figure 8: Production of xylanase enzyme by A. niger USM AI 1 and T. reesei under optimized fermentation conditions.

\section{CONCLUSION}

It can be concluded that about $50 \mathrm{U} / \mathrm{g}$ of xylanase activity was detected at the initial stage of SSF process and the enzyme production increased $681 \%$ to $390.8 \mathrm{U} / \mathrm{g}$ after all the factors affect the enzyme production had been examined. On the other hand, xylanase produced by $T$. reesei was about $44 \%$ higher compared with xylanase produced by $A$. niger USM AI 1. Furthermore, this shows that this newly designed solid state bioreactor
FERMSOSTAT, can be used to produce xylanase with high titer and the results obtained were comparable with previous researcher findings reported elsewhere.

\section{ACKNOWLEDGMENT}

This work was mainly financed by Intensive Research Priority Area (IRPA) grant from Ministry of Science, Technology and The Environment, Malaysia. The author would like to thank Universiti Sains Malaysia (USM) for given him USM Incentive grant and short term grant (304/PTEKIND/6312113). 


\section{REFERENCES}

Abdulah, A. L., Tengerdy, R. P. and Murphy, V. G. (1985). Optimization of solid substrate fermentation of wheat straw. Biotechnology and Bioengineering, 5(27), 20-27.

Aikat, K. and Bhattacharyya, B. C. (2000). Protease extraction in solid state fermentation of wheat bran by a local strain of Rhizopus oryzae and growth studies by the soft gel technique. Process Biochemistry 35, 907-914.

Banks, G. T. (1984). Scale up of fermentation processes. In: Topics in Enzyme and Fermentation Biotechnology. Wiseman, A. (ed). Ellis Horwood Limited, Chichester. pp. 170-266.

Biswas, S. R., Jana, S. C., Mishra, A. K. and Nanda, G. (1990). Production, purification and characterization of xylanase from a hyperxylanolytic mutant of Aspergillus ochraceus. Biotechnology and Bioengineering 35, 244-251.

Dechamps, F., Giuliano, C., Asther, M., Huet, M. C. and Roussos, S. (1985). Cellulase production by Trichoderma harzianum in static and mixed solid state fermentation reactors under nonaseptic conditions. Biotechnology and Bioengineering 27, 1385-1388.

Durand, A. and Chereau, D. (1988). A new pilot reactor for solid-state fermentation: Application to the protein enrichment of sugar beet pulp. Biotechnology and Bioengineering 31, 476-487.

Durand, A., Reynaud, R., Maratray, J., Almanza, S. and Diez, M. (1996). INRA-Dijon reactors for solid-state fermentation: Designs and applications. Journal of Scientific Industrial Research 55, 317-332.

Fernandez, M., Perez-Correa, J. R., Solar, I. and Agosin, E. (1996). Automation of a solid substrate cultivation pilot reactor. Bioprocess Engineering 16, 14.

Gessesse, A. and Gashe, B. A. (1997). Production of alkaline xylanases by an alkaliphilic Bacillus sp. isolated from an alkaline soda lake. Journal of Applied Microbiology 83, 402-406.

Gupte, A, and Madamwar, D. (1997). Solid state fermentation of lignocellulosic waste for cellulase and beta-glucosidase production by co-cultivation of Aspergillus ellipticus and Aspergillus fumigatus. Biotechnology Progress 13, 166-169.

Gutierrez-Correa, M. and Tengerdy, R. P. (1998). Xylanase production by fungal mixed culture solid substrate fermentation on sugar cane bagasse. Biotechnology Letter 20,45-47.

Hang, Y. D. and Woodams, E. E. (1998). Production of citric acid from corncobs by Aspergillus niger. Bioresource Technology 65, 251-253.

Kalogeris, E., Christakopoulos, P., Kekos, D., Macris, B. J. (1998). Studies on the solid state production of thermostable endoxylanases from Thermoascus aurantiacus. Characterization of two isoenzymes. Journal of Biotechnology 60, 155-163.

Kalogeris, E., Fountoukides, G., Kekos, D. and Macris, B. J. (1999). Design of a solid state bioreactor for thermophilic microorganisms. Bioresource Technology 67, 313-315.

Kalogeris, E., Iniotaki, F., Topakas, E., Christakopoulos, P., Kekos, D. and Macris, B. J. (2003). Performance of an intermittent agitation rotating drum type bioreactor for solid state fermentation of wheat straw. Bioresource Technology 86, 207-213.

Kapilan, R. and Arasaratnam, V. ( 2011). Paddy husk as support for solid state fermentation to produce xylanase from Bacillus pumilus. Rice Science 18(1), 36-45.

Kargi, F. and Curme, J. A. (1985). Solid state fermentation of sweet sorghum to ethanol in a rotary drum fermenter. Biotechnology and Bioengineering Journal 27, 1122-1125.

Kotwal, S. M., Gote, M. M., Sainkar, S. R., Khan, M. I. and Khire, J. M. (1998). Production of alphagalactosidase by thermophilic fungus Humicola sp. in solid state fermentation and its application in soya milk hydrolysis. Process Biochemistry 33, 337-343.

Krishna, C. (1999). Production of bacterial cellulases by solid state bioprocessing of banana wastes. Bioresource Technology 69, 231-239.

Kumar, P. K. R. and Lonsane, B. K. (1987). Potential of fed batch culture in solid state fermentation for production of gibberellic acid. Biotechnology Letter 9,179-182.

Kumar, P. K. R. and Lonsane, B. K. (1988). Batch and fed batch solid state fermentation: Kinetics of cell growth, hydrolytic enzymes production and gibberellic acid production. Process Biochemistry 23, 43-47.

Lee C. K., Darah, I. and Ibrahim, C. O. (2011). Production and optimization of cellulase enzyme using Aspergillus niger USM Al 1 and comparison with Trichoderma reesei via solid state fermentation system. Biotechnology Research International: Volume 2011. Article ID 658493. doi:10.4061/2011/658493.

Lonsane, B. K., Durand, A., Renaud, R., Almanza, S., Maratray, J., Desgranges, C., Crooke, P. S., Hong, K., Maloney, C. W. and Tanner, R. D. (1992a). Product leaching and downstream processing. In: Solid Substrate Cultivation. Doelle, H. W., Mitchell, D. A. and Rolz, C. W. (eds). Elsevier Science Publishers, London. pp. 147-171.

Lonsane, B. K., Saucedo-Castaneda, G., Raimbault, M., Roussos, S., Viniegra-Gonzalez, G., Ghildyal, N. P., Ramakrishna, M. and Krishnaiah, M. M. (1992b). Scale up strategies for solid state fermentation systems. Process Biochemistry 27, 259273.

Lonsane, B. K., Ghildyal, N. P., Budiatman, S. and Ramakrishna, S. V. (1985). Engineering aspects of solid state fermentation. Enzyme and Microbial Technology 7, 258-265.

Maldonado, de Saad., Maldonado, M. C. and de Saad, A. M. (1998). Production of pectinesterase and polygalacturonase by Aspergillus niger in submerged 
and solid-state systems. Journal of Industrial Microbiology and Biotechnology. 20, 34-38.

Milagres, A. M. F., Santos, E., Piovan, T. and Roberto, I. C. (2004). Production of xylanase by Thermoascus aurantiacus from sugar cane bagasse in an aerated growth fermentor. Process Biochemistry 39, 13871391.

Mitchell, D. A., Doelle, H. W. and Greenfield, P. F. (1988). Improvement of growth of Rhizopus oligosporus on a model solid substrate. Biotechnology Letter 18, 497-501.

Mitchell, D. A., Krieger, N., Stuart, D. M. and Pandey, A. (2000). New developments in solid state fermentation II. Rational approaches to the design, operation and scale up of bioreactors. Process Biochemistry 35, 1211-1225.

Mitchell, D. A., Meien, O. F. V., Luz, Jr. L. F. L. and Berovic, M. (2006). The scale up challenge for SSF Bioreactors. In: Solid State Bioreactors: Fundamentals of Design and Operation. Mitchell, D. A., Krieger, N. and Berovi, M. (eds). Springer-Verlag, Berlin Heidelberg, Germany. pp. 57-64.

Muhammad, I., Muhammad, N. and Quratulain, S. (2014). One-factor-at-a-time (OFAT) optimization of xylanase production from Trichoderma viride-IR05 in solid-state fermentation. Journal of Radiation Research and Applied Sciences 7, 317-326.

Ncube, T., Howard, R. L., Abotsi, E. K., Jansen van Rensburg, E. L. and Ncube, I. (2012). Jatropha curcas seed cake as substrate for production of xylanase and cellulase by Aspergillus niger FGSCA733 in solid-state fermentation. Industrial Crops and Products 37, 118-123.

Panagiotou, G., Kekos, D., Macris, B. J. and Christakopoulos, P. (2003). Production of cellulolytic and xylanolytic enzymes by Fusarium oxysporum grown on corn stover in solid state fermentation. Industrial Crops and Products 18, 37-45.

Pandey, A., Soccol, C. R. and Larroche, C. (2008). General consideration about solid state fermentation process. In: Current Developments in Solid State Fermentation. Pandey, A., Soccol, C.R. and Larroche, C. (eds). Springer Science Business Media, New York, USA. pp. 13-25.

Pang, P. K., Darah, I., Poppe, L. Szakacs, G. and Ibrahim, C. O. (2006). Xylanase production by local isolate, Trichoderma sp. FETL C3-2 via solid-state fermentation using agricultural wastes as substrates. Malaysian Journal of Microbiology 2, 7-14.

Pirota, R. D. P. B., Tonelotto, M., Delabona, P. D. S., Fonseca, R. F., Paixão, D. A. A., Baleeiro, F. C. F., Neto, V. B. and Farinas, C.S. (2013). Enhancing xylanases production by a new Amazon forest strain of Aspergillus oryzae using solid-state fermentation under controlled operation conditions. Industrial Crops and Products 45, 465- 471.

Raimbault, M. and Alazard, D. (1980). Culture method to study fungal growth in solid fermentation. European Journal of Applied Microbiology and Biotechnology 9, 199-209.
Ramesh, M. V. and Lonsane, B. K. (1990). Critical importance of moisture content of the medium in alpha-amylase production by Bacillus licheniformis M27 in a solid state fermentation system. Applied Microbiology and Biotechnology 3, 201-205.

Rodríguez-Fernández, D. E., Rodríguez-León, J. A. de Carvalho, J. C., Sturm, W. and Soccol, C. R. (2011). The behavior of kinetic parameters in production of pectinase and xylanase by solid-state fermentation. Bioresource Technology 102, 10657-10662.

Roussos, S., Raimbault, M., Saucedo-Castaneda, G., Viniegra-Gonzalez, G. and Lonsane, B. K. (1991). Kinetics and ratios of carboxymethyl cellulase and filter paper activities of the cellulolytic enzymes produced by Trichoderma harzianum on different substrates in solid state fermentation. Micologia Neotropical Aplicada 4, 19-40.

Sekar, C. and Balaraman, K. (1998). Optimization studies on the production of cyclosporin A by solid state fermentation. Bioprocess Engineering 18, 293296.

Shah, A. R. and Madamwar, D. (2005). Xylanase production under solid state fermentation and its characterization by an isolated strain Aspergillus foetidus in India. World Journal of Microbiology and Biotechnology 21, 233-243.

Silman, R. W. (1980). Enzyme formation during solid substrate fermentation in rotating vessels. Biotechnology and Bioengineering Journal 22, 411420.

Smits, J. P., Rinzema, A., Tramper, J., van Sonsbeek, H. M. and Knol, W. (1996). Solid-state fermentation of wheat bran by Trichoderma reesei QM9414: Substrate composition changes, $\mathrm{C}$ balance, enzyme production, growth and kinetics. Applied Microbiology and Biotechnology 46, 489-496.

Swift, J. (1972). The estimation of mycelial biomass by determination of the hexosamine content of wood tissues decayed by fungi. Soil Biological and Biochemistry 5, 321-322.

Trilli, A. (1986). Scale up of fermentation. In: Industrial Microbiology and Biotechnology. Demain, A. L. and Solomon, N. A. (eds). American Society of Microbiology, Washington, USA. pp. 227-307.

Xue, M., Liu, D., Zhang, H., Hongyan, Q. and Lei, Z. (1992). A pilot process of solid state fermentation from sugar beet pulp for the production of microbial protein. Journal of Fermentation and Bioengineering 73, 203205. 